\title{
Aydınlatma ile Güvenlik Algısı İlişkisinin Niğde Ömer Halisdemir Üniversitesi Yerleşkesi Örneğinde İncelenmesi
}

DOI: 10.26466/opus.560247

\author{
Orhun Soydan*- Ahmet Benliay** \\ * Dr., Niğde Ömer Halisdemir Üniversitesi, Mimarlık Fakültesi, Merkez / Niğde / Türkiye \\ E-Posta: dokrates87@hotmail.com \\ ORCID: 0000-0003-0723-921X \\ ** Dr., Akdeniz Üniversitesi, Mimarlık Fakültesi, Konyaaltı / Antalya / Türkiye \\ E-Posta: benliay@akdeniz.edu.tr \\ ORCID: 0000-0002-0902-2658
}

\begin{abstract}
Öz
Ülkemizdeki üniversite sayısı sürekli artmakta olup, bu üniversitelerden bazlları büyük yerleşke alanlarına dönüşmektedirler. Bu yüzden yerleşke alanları kentsel yaşam alanları içerisinde büyük bir öneme sahiptir. Yerleşke içerisinde bulunan öğrenciler, eğitim yanında konaklama, eğlence ve rekreasyonel faaliyetler için de yerleşke alanlarını kullanmaktadırlar. Bu yerleşkeler gündüz kullanıldı̆̆ı gibi akşam/gece de kullanılmaktadır. Bu alanların akşam/gece kullanımı açısından (güvenlik, estetik vb.) aydınlatma sistemleri tasarımı önemli bir yer tutmaktadır. Yerleşkeler içerisinde belirli alanlarda, aydınlatma tasarımının eksik olmasından dolayı karanlık alanlar oluşmakta, bunun sonucunda da yerleşke içerisinde güvenlik problemleri meydana gelmektedir. Aydınlatma eksikliği sonucunda yerleşke içerisinde başıboş gezen hayvanlar, fiziksel tehlikeler ve insanlarda saldırıya uğrama korkusu meydana gelmektedir. Bu eksiklikler yerleşkelerin gece kullanımını engellemektedir. Aydınlatmadan dolayı meydana gelen korkular, yerleşkenin yaşam kalitesini ve konforunu da azaltmaktadır. Bu çalışma da Niğde Ömer Halisdemir Üniversitesini kullanan öğrenciler, akademik ve idare personeller ile çalışanlar üzerinden anket çalışması (400 kişi) yürütülmüştür. Yapılan anket çalışması sonucunda; yerleşkeyi kullananların yerleşkenin aydınlatma tasarımına yönelik düşünceleri ve aydınlatma tasarımının kullanımların nasıl etkilediği belirlenmiştir. Ayrıca, yerleşke içerisinde aydınlatmaya bağlı olarak ortaya çıkan güvenlik problemleri yerleşke kullanıcllarının düşüncülerine göre tespit edilmiştir. Yerleşke içerisinde bulunan kullanım alanlarının aydınlatma tasarımı ile olan ilişkileri ve kullanıcıların yerleşke içerisinde kendilerini en çok ya da en az hangi alanlarda güvende hissettikleri tespit edilmiştir. Çalışma sonucunda; yerleşkeyi kullanan kişilerin aydınlatma tasarımına bağh olarak güvenlik algısını arttıracak önerilere yer verilmiştir.
\end{abstract}

Anahtar Kelimeler: Aydınlatma; Aydınlatma Tasarımı; Dış mekân; Niğde Ömer Halisdemir Üniversitesi Yerleşkesi; Güvenlik 


\title{
Investigation of the Relationship between Lighting and Security Perception in the Case of Niğde Ömer Halisdemir University Campus
}

\begin{abstract}
The number of universities is constantly increasing and some of these universities have been changed to large campuses in Turkey. Therefore, campus areas have a great importance in urban areas. Students use the campus areas for accommodation, leisure and recreational activities as well as education. Campuses are used during the night as well as during the day. Lighting systems design has an important issue in terms of night use of these areas (safety, aesthetics, etc.). Dark areas have been occurred because the lacks of lighting design in some areas in the campuses, resulting in security problems in the campuses. As a result of the lack of lighting, the animals rambling inside the campuses, physical dangers and fear of being attacked in humans occur. These deficiencies prevent the use of the campuses at night. Fears caused by lighting reduce the quality of life and the comfort of the campuses. In this study; survey was conducted on students, academic and administrative personnel and employees (400 people). As a result of the survey; user's opinion about the campus lighting design and how the lighting design affects their use were determined. In addition, security problems related to lighting in the campus were determined according to the opinions of the users of the campus. The relationship between the lighting design and the usage areas in the campus and areas where are the users feel most secure or at feel most least have been determined. In the result of the study; the suggestions have been included to increase the perception of security depending on the lighting design for people who use the campus.
\end{abstract}

Keywords Lighting; Lighting design; Outdoor, Niğde Ömer Halisdemir University Campus, Security 


\section{Giriş}

Kentlerde yaşayan insan sayısının günden güne artmasıyla birlikte, kentlerin kullanıcılara sunduğu imkânlar değişmekte, kimi zaman da yetersiz kalmaktadır. Kent imkânlarıyla ilişkili olan kentsel yaşam kalitesindeki bu yetersizlik, kullanıcıların kente olan bağlllıklarını ve güvenlerini zedeleyip, aidiyet ve memnuniyet duygularının azalmasına yol açmaktadır. Bu nedenle; toplumların huzur ve refahının sağlanmasında önemli yeri olan kentsel yaşam kalitesi, kentlerin geleceğine yönelik çalışmalarda öncelikle ele alınması gereken konuların başında gelir.

Kentlerdeki yaşam kalitesinin belirleyici unsurlarından biri, kentlilerin hem güvenlik hem de estetik ihtiyaçlarına cevap veren kentsel aydınlatmadır (Emür, 2007, s.14). Aydınlatma; insanın doğası gereği yaşaması için gerekli olan en temel unsurlardandır. İnsan, içerisinde bulunduğu fiziksel ortamı; 1şık, renk, ses, 1sı, nem, hava ve koku sayesinde algılamaktadır. Bu unsurlar arasından ışık, insanların değişik algılar yolu ile edindikleri bilgilerin \% 95'inin görsel alg1 yoluyla olması sebebiyle büyük önem taşımaktadır (Öztürk ve Ünver, 1992, s.27). Görme duyumuzun çalışması için aydınlatmanın var olmasına, dolayısıyla bir ışık kaynağına ihtiyaç duymaktayız. Açık alanların aydınlatılması, güvenlik ve estetik olmak üzere 2 bölümde incelenebilmektedir. Açık alanların aydınlatılması tasarımına başlarken, güvenlik ve estetik konuları dikkate alınmalıdır. Projede bazen bunlardan birisi daha ön plana çıkabilmektedir. Ancak mümkün olduğunca, estetiğin ön plana çıktığı hoş görünümlü aydınlatma kompozisyonuna güvenlik elemanları da eklenmelidir (Seçkin, 1998, s.24 ).

Kent öğesi içerisinde üniversiteler önemli bir yere sahiptirler. Üniversiteler bulundukları kentlere sayısız katkı sunar. Bir üniversite bulunduğu kent için insan kaynakları, bilgi, eğitim, iş ve sosyal hizmetler konusunda önemli bir kaynaktır. Bu katkının karşılıklı artabilmesi için üniversitelerin bulundukları kentlerde algılanma düzeyleri ve biçimlerinin geliştirilmesi, kent ile üniversite arasında hangi alanlarda işbirliklerinin geliştirilebileceğinin belirlenmesi ve ortak çalışmalardan bilgi transferi yapılabilmesi önemlidir (Sankır ve Gürdal, 2014, s.25).

Kentler insanlara barınma, dinlenme, eğitim vb. gibi çoklu işlevler sunan yaşam alanlarıdır. Kentler bu işlevlerinden dolayı konutları, tica- 
ret merkezlerini, ulaşım alanlarını, ormanları ve yeşil alanları içerisinde bulundurmaktadırlar. Yerleşkeleri bu kavramlar içerisinde "aktif yeşil alanlar" olarak değerlendirmek mümkündür. Yerleşkeler kentsel açı yeşil alanlar açısından oldukça büyük öneme sahiptirler. Kent içerisinde büyük alanlara dönüşen üniversite yerleşkeleri, sahip oldukları öğrenci ve personel sayıları, rekreasyon faaliyetleri gibi nedenlerden dolayı büyük yerleşim alanlarına dönüşmektedirler. Bu yüzden kent içerisindeki azalan aktif yeşil alan varlığının arttırılması amacıyla yerleşke tasarımları çok büyük bir öneme sahiptirler.

Ülkemizde bulunan üniversitelerin sayısı her geçen yıl artmaktadır. Kurulan bu üniversiteler, büyük bir yerleşke alanına ihtiyaç duymaktadırlar. Bu alanların kurulumu için tercih edilen alanlar ise bulundukları kentlere kattıkları değerler açısından oldukça önemli bir yere sahiptirler. Kurulan yerleşke alanları kentlerin çekim merkezi durumuna gelmekte ve birçok kişi tarafından çeşitli nedenlerle kullanılmaktadırlar. Bu yüzden kent içerisindeki gerek yaşam kalitesi gerekse sürdürülebilirlik aç1sından yerleşke tasarımının tüm yönleriyle ele alınması gerekmektedir.

Aydınlatma tasarımı yerleşkenin sürekli kullanımı açısından öneme sahiptir. Yerleşkelerin gece kullanımının artırılması sağlanmalıdır. Yerleşkelerin eğitim - öğretim, yurt, kütüphane, araştırma vb. nedenlerden dolayı akşam/gece kullanımının da sağlanması gerekmektedir. Bu da ancak iyi planlanmış ve tasarlanmış aydınlatma ile mümkün olabilmektedir. İyi bir aydınlatma tasarımı ile kullanıcılarının akşam kullanımının da artırılması sağlanabilir.

Bir üniversite kampüsünün ve tesislerinin tasarımı ve düzeni nedeniyle kişisel güvenlik konusu çok önemlidir. Kampüsler genellikle geniş açık alanlardır ve sistematik erişim kontrolünden yoksundurlar, bu da kampüs kullanıcılarının mağduriyet ve korku yaşamalarına zemin oluşturmaktadır. Araştırmalar, üniversite kampüslerindeki suç korkusunun fiziksel ortamın farklı özelliklerinden etkilenebileceğini ortaya koymaktadır. Kampüslerin tasarım özellikleri ve fiziksel düzenleriyle bağlantılı olarak belirli suçlara ve kişisel güvenlik kaygılarına neden olması, genç ve savunmasız öğrencilerin suç ve kişisel güvenlik olaylarını yaşamalarina neden olmaktadır (Waters, Neale ve Mears, 2005, s.231).

Güvenlik kavramının tanımı yapılırken birçok değişkenin dikkate alınması gerekliliği ve değişen şartlara göre kavramın çerçevesinin yeni- 
den belirlenmesi durumu herkes tarafından kabul gören ve her dönem geçerli olan bir tanımın ortaya çıkmasına engel olmaktadır. Bununla birlikte güvenliğe ilişkin "tehlikelerden ve korkulardan uzak kalma, bir tehdidin olmaması" gibi ifadelerin birçok tanımda kullanılmış olması ortak bir anlayışın olduğunu da göstermektedir (Özcan, 2011, s.447) Buradan anlaşılacağı üzere güvenlikle tehdit arasında doğrudan bir ilişki vardır ve güvensizlik durumu bir tehdidin var olduğuna işaret etmektedir. Sözü edilen tehdit bir yanıyla gerçek olgulara ve olaylara dayanmakta iken, bir yanıla da algı ve tahminlere dayanmaktadır (Dedeoğlu, 2008, s.22). Objektif güvenlik, bir tehlikenin var olmadığını, sübjektif güvenlik ise şüphelenilecek bir tehlikenin olmadığına inanma durumunu ifade etmektedir (Caşın, Özgöker ve Çolak, 2007, s.64).

İnsanın kentsel mekân ölçeğindeki ihtiyaçları; temel ihtiyaçlar, bilişsel ihtiyaçlar ve estetik ihtiyaçlar olarak sınıflandırılmıs, temel ihtiyaçlar da kendi içerisinde; fizyolojik ihtiyaçlar, güvenlik ve korunma ihtiyacı, aidiyet ihtiyacı, saygı görme ihtiyacı ve kendini ifade etme ihtiyacı olarak sınıflandırılmıştır (Lang, 1994, s.67). Maslow (1970)'un gereksinimler hiyerarşisinde sıraladığı gibi, güvenli bir ortam gereksinimi çoğunlukla insanların diğer gereksinimlerinin önüne geçmektedir. Bir başka deyişle insanların güvenlik ihtiyacı temel ihtiyaçlarından sonra gelen en önemli ihtiyaçlarındandır. Bu ihtiyacı karşılanmadı̆̆ında diğer ihtiyaçlarının giderilmesi mümkün olamayacaktır (Gök, 2018, s.2).

Rund'a göre (2002, s.8), Güvenli bir kampüs öğrencilere akademik potansiyellerini, ayrımcllı ve sindirmeden uzak ya da fiziksel ve psikolojik esenliklerine yönelik tehdit içermeyen bir ortamda sürdürme olanağ1 sağlayan bir kampüstür. Güvenli bir kampüs, güvenlik için izlenen, fiziksel çevrenin rutin olarak izlendiği ve uygun şekilde düzenlemelerin yapıldığı bir yerdir. Böyle bir fiziksel çevrenin oluşturulması, kurumsal bir sorumluluktur ve kurum içinde birden çok tarafın katılımını ve taahhüdünü gerektirir. Kampüste güvenlik için genellikle birincil rolü öğrencilerin refahıyla ilgilenmekle yükümlü olan güvenlik birimi ve öğrenci işleri sorumludur. Kampüste güvenliği sağlamak için tehditleri ortadan kaldırarak kararlı ve düzeltici önlemler alınmalıdır (Çelik, Gemici ve Mirza, 2018, s.4).

Güvenli kampüs, öğrenci, akademisyen ve üniversite çalışanlarının kendilerini fiziksel, psikolojik ve sosyal bakımdan özgür hissettikleri 
yerdir. Güvenli kampüs, yüksek ölçekli güvenlik algısına ve uygulamalarına sahip, özgür ve güvenli bir iklimi, birbirine değer veren, üniversiteye bağlılık hissiyle dolu akademik ve evrensel eğitime odaklanmış öğrenci ve öğretim üyeleri, uyum ve uzlaşıyla oluşturulmuş kuralları, olası suç olgularına karşı önceden saptanmış plan ve projeleri bulunan proaktif bir güvenlik algısının etkin ve yetkin olduğu, sosyal, sanatsal, sportif ve kültürel etkinliklerle renklendirilmiş bahçesi gençlerle canlanan bir kampüstür. Güvenli bir kampüs ortamı öğrenciler için okula bağlllık, derslere odaklanma ve akademik başarıyı da beraberinde getirmektedir (Öztürk, 2014, s.50). Bu nedenle günümüzde giderek büyüyen yerleşkelerde artan güvenlik sorunları nedeniyle yerleşkelerde yapılacak çalışmalarda, kullanıcıların güvenliğini artırmaya yönelik peyzaj tasarımı ve uygulamalarının ortaya konulması peyzaj mimarlığı disiplini aç1sından güncel ve önemli bir konudur. Peyzaj tasarımı ve güvenlik ilişkisi üzerinde uluslararası çok sayıda araştırma bulunmasına rağmen ülkemizde bu ilişkiyi ortaya koymaya yönelik araştırmalar yok denecek kadar azdır. Dolayısıyla insanların yerleşkeler ile ilgili güvenlik algısını belirlemeye çalışmak oldukça önemlidir

Bu çalışmanın temel amacı; Niğde Ömer Halisdemir Üniversitesi yerleşkesi kullanıcıların aydınlatma tasarımına bağlı olarak güvenlik algılarının belirlenmesidir. Bu amaçla yerleşke kullanıcılara anket çalışması uygulanmış; elde edilen veriler doğrultusunda yerleşkede aydınlatmaya bağlı olarak sorunların neler olduğu ve yerleşke içerisinde aydınlatma açısından sorunlu alanlar tespit edilmiş, elde edilen veriler ışığında yerleşkenin aydınlatmasına yönelik öneriler geliştirilmiştir.

\section{Materyal Ve Yöntem}

\section{Materyal}

Kentsel mekânlarda aydınlatma sorunlarının tespitini yapmak, bu sorunların giderilerek kentsel yaşam kalitesinin artırılmasına yönelik öneriler geliştirmek üzere Niğde Ömer Halisdemir Üniversitesi Yerleşkesi çalışma alanı olarak tercih edilmiştir. Niğde Ömer Halisdemir Üniversitesi Yerleşkesi, 24 saat boyunca kullanılan içerisinde barınma, eğitim, sosyal ve kültür merkezleri, spor alanları ve yeşil alanlar gibi farklı faaliyetlerin 
bir arada bulunduğu kentsel bir mekân olması ve sağlıklı bir gece aydınlatmasına ihtiyaç duyulması nedeniyle tercih edilmiştir. Yerleşke alanın sürekli değişim ve gelişim içerisinde olması nedeniyle, yerleşke gereksinimleri sürekli değişim göstermektedir. Yerleşkenin Niğde İl'indeki konumu Şekil 1' de verilmiştir.

\section{Niğde Ömer Halisdemir Üniversitesi}

1992 yılında kurulan Niğde Ömer Halisdemir Üniversitesi Yerleşkesi Niğde İl Merkezi ile Bor İlçesi sınırları arasında bulunmaktadır. Yerleşke, Atatürk Bulvarı üzerinde bulunan Tevfik Çalın Caddesi üzerinde bulunmaktadır. Yerleşkenin doğusunda Bor ilçesi, batısında Niğde İl merkezi, güneyinde Sazlıca mahallesi, kuzeyinde ise Fertek ve Koyunlu mahalleleri bulunmaktadır. Yerleşke Niğde İl merkezine $5 \mathrm{~km}$, Bor ilçesine ise 6,5 km uzaklıktadır (Şekil 1). Niğde İlinde bulunan Akkaya Barajı da yerleşke sınırları içerisinde yer almaktadır. Üniversite'nin 21 tane akademik birimi bulunmaktadır: Bu birimler; dokuz fakülte, üç yüksekokulu, altı meslek yüksekokulundan oluşmaktadır.

Bu okullardan üç tanesi (bir yüksekokul ve iki meslek yüksekokulu) Bor İlçesi'nde, bir tanesi ise (bir meslek yüksekokulu) Ulukışla İlçesi'nde yer almaktadır. Niğde Ömer Halisdemir Üniversitesi yerleşkesi yaklaşık $2.152 .940 \mathrm{~m}^{2}$ (215 hektar) alana sahiptir. Yerleşkenin güncel durumuna bakıldığında yüz ölçümünün yaklaşık \% 35'lik kısmında yapıların, geriye kalan \% 65'lik kısmında ise yeşil alanların olduğu görülmektedir. Niğde Ömer Halisdemir Üniversitesi Yerleşkesinin güncel aydınlatma durumunun kullanıcılar üzerindeki etkisinin belirlenmesi amacıyla yerleşke içerisinde bulunan öğretim elemanları, öğrenciler, idareciler üzerinde anket çalışması yapılmıştır. Niğde Ömer Halisdemir Üniversitesi Yerleşkesi içerisinde toplam 29.317 kişi bulunmaktadır. Yerleşke içerisinde 27.800 öğrenci, 889 akademik personel, 527 idari personel ve 100 çalışan bulunmaktadır. Evren büyüklüğü 25.000 ile 50.000 kişi arasında olan alanlar için \% 95 güven aralığında yapılması gereken anket sayısı 378'dir (Yazıcıoğlu ve Erdoğan, 2004, s.7). Çalışmanın doğruluğu açısından anket sayısı 400 kişi olarak belirlenmiştir. 


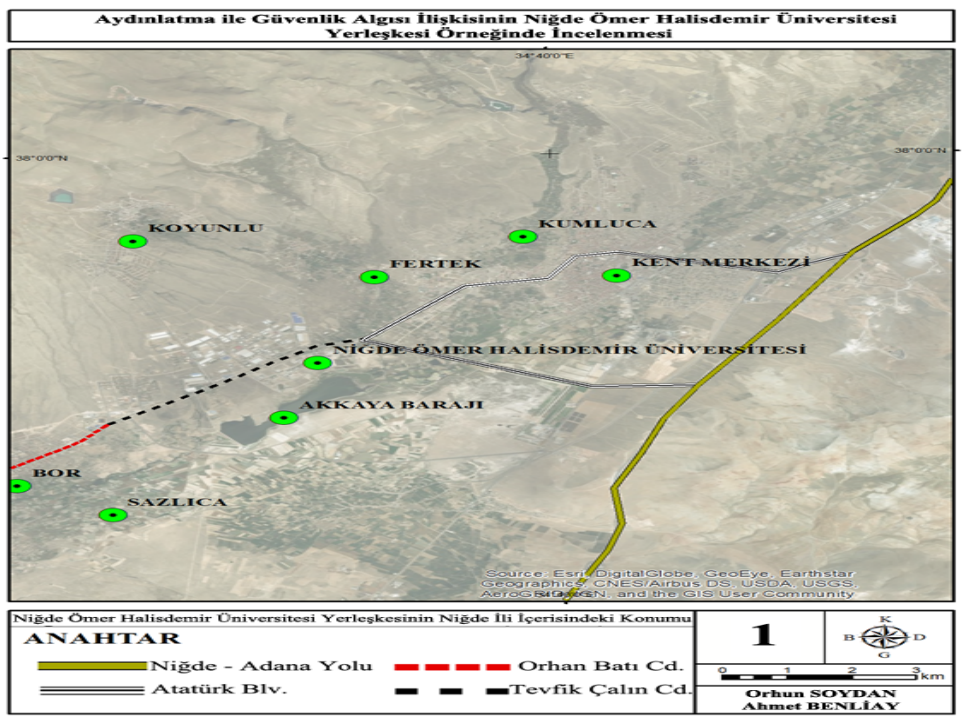

Şekil 1. Niğde Ömer Halisdemir Üniversitesi Yerleşkesinin Niğde İli içerisindeki konumu

\section{Metod}

Bu çalışmada; anket ve ölçek tekniğine dayalı niceliksel sorgulama yöntemine göre öğrencilerin Niğde Ömer Halisdemir Üniversitesi yerleşkesine ilişkin güvenlik algıları belirlenmeye çalışılmıştır. Araştırmada öğrencilerin kişisel bilgilerinin belirlenmesine yönelik kapalı uçlu anket sorularının yanı sıra yerleşkede güvenlik algısını belirlemek amacıyla oluşturulan ölçek kullanılmıştır. Yerleşkede güvenlik algısı düzeyini belirlemek için oluşturulan önermeler 5'li likert ölçeği ile derecelendirilmiştir.

Çalışma yerleşke üzerinde bulunan 27.800 öğrenci üzerinden yürütülmüştür. Niğde Ömer Halisdemir Üniversitesi yerleşkesi üzerinde gündüz ve gece alan çalışması yapılmış, fotoğraf çekilmiş ve güvenlik açısından sıkıntı oluşturabilecek yerler ve durumlar belirlenmiştir. Bu analizler sonucunda oluşturulan anket çalışması ise 2018 yılı Haziran ayında yüz yüze görüşülerek yapılmıştır. Çalışmada anketlerin değerlendirilmesi aşamasında güven aralığ $\% 95$ ve anlamlılık düzeyi $p<0,05$ olarak alınmıştır. Elde edilen verilerin analizinde, Excel ve SPSS 21.00 sosyal bilimler için istatistik paket programı kullanılmış; betimleyici ista- 
tistikler için yüzde dağılımları, frekans ve korelasyon analizi uygulanmış; güvenirlik analizi için anova analizi ve t testi yapılmıştır.

\section{Araştırma Bulguları}

\section{Niğde Ömer Halisdemir Üniversitesi}

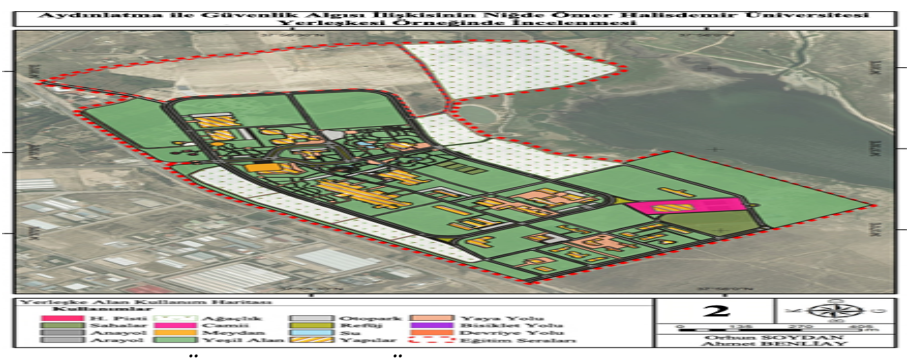

Şekil 2. Ni⿱̆gde Ömer Halisdemir Üniversitesi Yerleşkesi alan kullanım haritası

Niğde Ömer Halisdemir Üniversitesi yerleşkesinin güncel alan kullanım tipleri ve kapladıkları alanlar Arc-GIS yazılımı kullanılarak belirlenmiş ve tipleri Şekil 2 ve Tablo 1'de verilmiştir. Yerleşkenin \% 64,30'nun yeşil alan ile kaplı olduğu, fakülte, yönetim binaları ve dersliklerin yerleşke içerisindeki oranının \% 5,16 olduğu tespit edilmiştir.

Tablo 1. Niğde Ömer Halisdemir Üniversitesi Yerleşkesi alan kullanımı

\begin{tabular}{llllll}
\hline Kullanım & Alan (ha) & $\begin{array}{l}\text { Yüzde } \\
\mathbf{( \% )}\end{array}$ & Kullanım & $\begin{array}{l}\text { Alan } \\
\text { (ha) }\end{array}$ & $\begin{array}{l}\text { Yüzde } \\
\text { (\%) }\end{array}$ \\
\hline Anayol & 7,756 & 3,60 & Helikopter Pisti & 0,025 & 0,01 \\
\hline Ara yol & 5,854 & 2,72 & Meydan & 0,110 & 0,05 \\
\hline Bisiklet Yolu & 1,656 & 0,77 & Otopark & 2,548 & 1,18 \\
\hline Devriye Yolu & 2,153 & 1,00 & Refüj & 2,627 & 1,22 \\
\hline Eğitim Seraları & 28,427 & 13,20 & Saha & 0,509 & 0,24 \\
\hline Su & 0,356 & 0,17 & Toplanma Alanı & 0,528 & 0.25 \\
\hline Yapılar & 11,107 & 5,16 & Yaya Yolu & 13,208 & 6,16 \\
\hline Yeşil Alan & 138,430 & 64,30 & & & \\
\hline Toplam & & 215,294 ha & & \\
\hline
\end{tabular}

Niğde Ömer Halisdemir Üniversitesi Yerleşkesi üzerinde toplam 9 Fakülte, 3 Meslek Yüksekokulu ve 3 yüksekokul bulunmaktadır. Yerleşke kullanım alanlarına göre 7 sinıfa ayrılmaktadır. Bunlar, anayollar, ara yollar, devriye yolları otoparklar, yeşil alanlar bisiklet yolu ve spor saha- 
larıdır. Yerleşke içerisinde bulunan yeşil alanlar, çok yoğun kullanılan, orta yoğunlukta kullanılan ve az kullanılan yeşil alan olarak 3 ayrı sınıfta incelenmiştir. Yerleşke yoğun olarak kullanılan alana ait görsel Şekil 3'de verilmiştir.

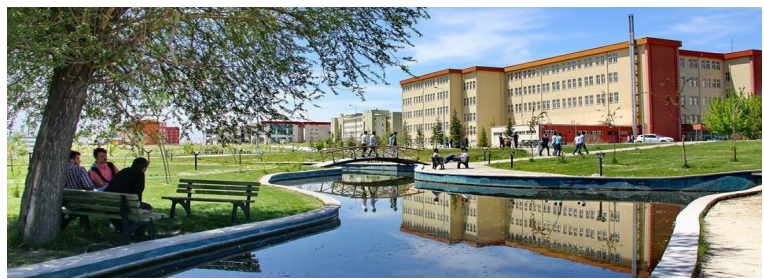

Şekil 3. Yerleşke ortak kullanım alanları

\section{Anket Çalışmasının Değerlendirilmesi}

Yerleşkenin güncel aydınlatması hakkında kullanıcı görüşlerini almak üzere anket çalışması yürütülmüştür. Anket toplam 400 kişiye uygulanmıştır. Anket çalışmasına katılanların cinsiyetleri Tablo 2'de verilmiştir.

Tablo 2. Katılımcilarin cinsiyetleri

\begin{tabular}{lllll}
\hline Sorular & Cevaplar & Sayı & Yüzde & Sh \\
\hline \multirow{2}{*}{ Cinsiyetiniz } & Erkek & 229 & 57,2 & \multirow{2}{*}{495} \\
\cline { 2 - 4 } & Kadın & 171 & 42,8 & \\
\hline
\end{tabular}

Anket çalışmasına katılanların \% 57,2'si erkek, \% 42,8'i ise kadındır. Anket çalışmasına katılanların yaş dağılımı ise Tablo 3'de verilmiştir.

Tablo 3. Katılımcıların yaş grupları dağılımı

\begin{tabular}{|c|c|c|c|c|}
\hline Sorular & Cevaplar & Sayı & Yüzde & Sh \\
\hline \multirow{7}{*}{ Yaşınız } & $15-20$ & 19 & 4,8 & \multirow{7}{*}{1,411} \\
\hline & $21-25$ & 241 & 60,3 & \\
\hline & $26-30$ & 48 & 12,0 & \\
\hline & $31-35$ & 35 & 8,8 & \\
\hline & $36-40$ & 27 & 6,8 & \\
\hline & $41-50$ & 18 & 4,3 & \\
\hline & $51-60$ & 12 & 3,0 & \\
\hline
\end{tabular}

Çalışmaya katılanların \% 60,3'ünün 21 - 25 yaş aralığında, \% 12,0'ının ise 26 - 30 yaş aralığında olduğu tespit edilmiştir. Çalışmaya katılanların eğitim durumları Tablo 4'de gösterilmiştir. 
Tablo 4. Katılımcıların eğitim durumları

\begin{tabular}{lllll}
\hline Sorular & Cevaplar & Sayı & Yüzde & Sh \\
\hline \multirow{4}{*}{$\begin{array}{l}\text { Eğitim } \\
\text { Durumunuz }\end{array}$} & Ilköğretim & 21 & 5,3 & \\
\cline { 2 - 4 } & Ortaöğretim & 17 & 4,1 & \multirow{2}{*}{, 970} \\
\cline { 2 - 5 } & Lisans & 267 & 66,8 & \\
\cline { 2 - 5 } & Y. Lisans & 26 & 6,5 & \\
\cline { 2 - 5 } & Doktora & 69 & 17,3 & \\
\hline
\end{tabular}

Çalışmaya katılanların \% 66,8'inin eğitim durumunun lisans, \% 17,3ünün ise doktora olduğu belirlenmiştir. Çalışmaya katılanların \% 98,3'ünün gece/akşam saatlerinde yerleşkeyi kullandığı tespit edilmiştir. Katılımcıların yerleşkeyi akşam/gece kullanma durumları Tablo 5'de verilmiştir.

Tablo 5. Katılımcılarnn yerleşkeyi akşam/gece kullanma durumu

\begin{tabular}{|c|c|c|c|c|}
\hline Sorular & Cevaplar & Sayı & Yüzde & Sh \\
\hline \multirow{6}{*}{$\begin{array}{l}\text { Yerleşkeyi gece/akşam } \\
\text { kullanıyorsanız daha çok hangi } \\
\text { saatler arasında kullanıyorsunuz? }\end{array}$} & $18.00-19.00$ & 371 & 92,8 & \multirow{6}{*}{ 259 } \\
\hline & $19.00-20.00$ & 301 & 75,3 & \\
\hline & $20.00-21.00$ & 156 & 39,0 & \\
\hline & $21.00-22.00$ & 58 & 14,5 & \\
\hline & $22.00-23.00$ & 5 & 1,3 & \\
\hline & $23.00-24.00$ & 0 & 0,0 & \\
\hline
\end{tabular}

Katılımcların \% 92,8'inin 18.00 - 19.00, \% 75,3'ünün ise 19.00 - 20.00 saatleri arasında yerleşkeyi daha çok kullandıkları tespit edilmiştir. Katılımcıların \% 52,0 (208 kişi) 'sinin yerleşkeyi güvenli bulmadığı, \% 48,0'ının (192 kişi) ise yerleşkeyi güvenli buldukları tespit edilmiştir. Katılımcıların \% 94,3'ü (377 kişi) aydınlatma etmeninin güvenliği etkilediğini düşünmektedirler. Katılımcıların \% 83,8'inin (335 kişi) yerleşkedeki güncel aydınlatma tasarımının kullanımlarını etkilediğini düşündükleri tespit edilmiştir. Katılımcıların \% 84,3'ünün (337 kişi) yerleşkenin aydınlatma tasarımından dolayı gözlerinde herhangi bir kamaşma oluşmadığını belirtirmişlerdir. Katılımcıların \% 79,0'ı (316 kişi) yerleşke içerisinde karanlık olduğundan dolayı görülmeyen alanlar olduğunu belirlenmişlerdir. Katılımcıların yerleşke aydınlatması ile ilgili sorulara vermiş oldukları cevaplar belirli gruplar halinde sınıflandırılmıştır. Buna göre cevapları "Evet-Hayır-Kısmen" olan sorular birleştirilerek tek tablo 
halinde sunulmuştur. Cevabı bu "Evet-Hayır-Kısmen" olan sorular şu şekildedir;

- S1: Yerleşkedeki genel aydınlık düzeyi sizce yeterli mi?

- S2: Yerleşkedeki aydınlatma elemanlarının sayısını yeterli buluyor musunuz?

- S3: Yerleşkedeki güncel aydınlatma armatürlerini bakımlı (cam kırıklığı, camın kirli olması, lambanın çalışmıyor olması vb.) buluyor musunuz?

- S4: Yerleşke içerisinde bulunan aydınlatma elemanlarını estetik buluyor musunuz?

- S5: Yerleşkede geceleri çevrenizi algılamakta sorun yaşıyor musunuz?

- S6: Yerleşkede bulunan bilgilendirme levhalarının aydınlatmaları yeterli mi?

- S7: Açık - Yeşil Alanlarda özel bir aydınlatma sistemi bulunsun ister misiniz?

Katılımcıların bu sorulara vermiş oldukları cevapları Tablo 6'da verilmiştir.

Tablo 6. Katılımcıların yerleşkenin aydınlatma durumu düşünceleri - 1

\begin{tabular}{|c|c|c|c|c|c|c|c|c|c|}
\hline Sorular & & & & & & & & & \\
\hline S1 & & & & S2 & & & S3 & & \\
\hline & $\mathrm{A}$ & B & C & $\mathrm{A}$ & B & C & A & B & C \\
\hline Evet & 84 & 21,0 & \multirow{3}{*}{,803 } & 59 & 14,7 & \multirow{3}{*}{ 734 } & 136 & 34,0 & \multirow{3}{*}{879} \\
\hline Hayır & 96 & 24,0 & & 116 & 29,0 & & 87 & 21,8 & \\
\hline Kismen & 220 & 55,0 & & 225 & 56,3 & & 177 & 44,2 & \\
\hline \multirow[t]{2}{*}{ S4 } & & & & S5 & & & S6 & & \\
\hline & A & B & C & A & B & C & A & B & C \\
\hline Evet & 115 & 28,7 & \multirow{3}{*}{,842 } & 119 & 29,7 & \multirow{3}{*}{ 769 } & 88 & 22,0 & \multirow{3}{*}{,751 } \\
\hline Hayır & 107 & 26,8 & & 164 & 41,0 & & 166 & 41,5 & \\
\hline Kismen & 178 & 44,5 & & 117 & 29,3 & & 146 & 36,5 & \\
\hline \multicolumn{10}{|l|}{ S7 } \\
\hline & A & $B$ & C & \multirow{4}{*}{\multicolumn{2}{|c|}{$\begin{array}{l}\text { A: Sayı } \\
\text { B: Yüzde } \\
\text { C: Standart Hata }\end{array}$}} & & & & \\
\hline Evet & 304 & 76,0 & \multirow{3}{*}{ 786 } & & & & & & \\
\hline Hayır & 48 & 12,0 & & & & & & & \\
\hline K1smen & 48 & 12,0 & & & & & & & \\
\hline
\end{tabular}

Katılımcıların \% 55,0'ının yerleşkenin genel aydınlık durumunu kısmen yeterli bulduğu, \% 24, $0^{\prime}$ ının ise yeterli bulmadığı tespit edilmiştir. 
Katılımcıların \% 56,3'ünün yerleşke içerisinde bulunan aydınlatma elemanı sayılarını kısmen yeterli buldukları, \% 29,0'ının ise yetersiz buldukları tespit edilmiştir. Katılımcıların \% 44,2'sinin yerleşkede bulunan aydınlatma elemanlarını kısmen bakımlı olduklarını, \% 34,0'ının ise aydınlatma elemanlarının bakımlarının yeterli olduklarını düşündükleri tespit edilmiştir. Katılımcların \% 44,5'i yerleşke içerisinde bulunan aydınlatma elemanlarını kısmen estetik bulurken, \% 28,7'si estetik bulmaktadırlar. Katılımcıların \% 41,0'ı yerleşkeyi gece algılama da kısmen sorun yaşıyorken, \% 29,7'sinin hiç sorun yaşamadığı tespit edilmiştir. Katılımcıların \% 41,5'i bilgi levhalarının aydınlatılmasının yeterli olmadığını, \% 36,5'i ise kısmen yeterli olduğunu belirtmişlerdir. Katılımcıların \% 76,0'ının açık yeşil alanlarda özel bir aydınlatma olmasını isterken, \% 12,0'ı ise istememektedir. Katılımcıların yerleşkenin aydınlatma tasarımı ile ilgili düşünceleri Tablo 7'de verilmiştir.

Tablo 7. Katılımcıların yerleşkenin aydınlatma durumu düşünceleri - 2

\begin{tabular}{lllll}
\hline Sorular & Cevaplar & Sayı & Yüzde & Sh \\
\hline \multirow{2}{*}{$\begin{array}{l}\text { Yerleşkenin gece } \\
\text { genel olarak nasıl } \\
\text { değerlendirirsiniz? }\end{array}$} & Yeterli & 82 & 20,5 \\
\cline { 2 - 4 } & Yetersiz & 73 & 18,3 \\
\cline { 2 - 4 } & $\begin{array}{l}\text { Daha Başarılı } \\
\text { Olabilir }\end{array}$ & 245 & 61,2 \\
\hline
\end{tabular}

Katılımcıların \% 61,2'si yerleşkenin genel aydınlatma durumunun daha iyi olabileceğini belirtirken, \% 20,5'i yerleşkenin aydınlatma tasarımının yeterli olduğunu belirtmişlerdir. Katılımcıların yerleşkeyi kullanma durumları Tablo 8'de verilmiştir.

Tablo 8. Katılımcıların yerleşke kullanma dönemleri

\begin{tabular}{|c|c|c|c|c|}
\hline Sorular & Cevaplar & Sayı & Yüzde & Sh \\
\hline \multirow{5}{*}{$\begin{array}{l}\text { Yerleşkeyi en çok hangi } \\
\text { aylarda kullanırsınız? }\end{array}$} & Aralık-Ocak-Şubat & 213 & 53,3 & \multirow{5}{*}{,499 } \\
\hline & Mart-Nisan May1s & 227 & 56,8 & \\
\hline & Haziran-Temmuz-Ağustos & 45 & 11,3 & \\
\hline & Eylül-Ekim-Kasım & 180 & 45,0 & \\
\hline & Her Zaman & 178 & 44,5 & \\
\hline
\end{tabular}

Katılımcıların \% 56,8'i yerleşkeyi en çok Mart-Nisan-Mayıs aylarında kullanırken, \% 53,3'ünün Aralık-Ocak-Şubat aylarında kullandıkları tes- 
pit edilmiştir. Katılımcıların yerleşkeyi kullanma amaçları Tablo 9'da verilmiştir.

Katılımcıların \% 48,5'i yerleşkeyi akşamları "dersten çıkmış olmak" amacıyla kullanıyorken, \% 26,5'i üniversitede görevli olduğundan dolayı yerleşkeyi akşam/gece kullandıkları tespit edilmiştir. Katılımcıların \% 70,3'ü yerleşkedeki aydınlatma yetersizliğinden dolayı kendileri güvende hissetmezken, \% 61,5'i yerleşke içerisinde başıboş dolaşan hayvanlar yüzünden kendilerini güvende hissetmediklerini belirtmişlerdir

Tablo 9. Katılımcıların yerleşkeyi akşam/gece kullanma nedenleri

\begin{tabular}{|c|c|c|c|c|}
\hline Sorular & Cevaplar & Say1 & Yüzde & Sh \\
\hline \multirow{7}{*}{$\begin{array}{l}\text { Akşam/Gece } \\
\text { yerleşkeyi kullanma } \\
\text { amacınız } \\
\text { nedir? }\end{array}$} & Spor etkinlikleri & 84 & 21,0 & \multirow{7}{*}{,407 } \\
\hline & Dersten çıkmış olmak & 194 & 48,5 & \\
\hline & Üniversitede görevli olmak & 106 & 26,5 & \\
\hline & Kütüphanede ders çalışmak & 99 & 24,8 & \\
\hline & Alışveriş yapmak & 38 & 9,5 & \\
\hline & Yurtta kalıyor olmak & 79 & 19,8 & \\
\hline & Sosyal etkinlik & 80 & 20,0 & \\
\hline
\end{tabular}

Katılımcıların akşam/gece kendilerini yerleşkede güvende hissetmeme nedenleri hakkındaki görüşleri Tablo 10'da verilmiştir.

Tablo 10. Katılımcıların yerleşkede kendilerini güvende hissetmeme nedenleri

\begin{tabular}{lllll}
\hline Sorular & Cevaplar & Say1 & Yüzde & Sh \\
\hline \multirow{3}{*}{$\begin{array}{l}\text { Gece/Akşam yerleşke } \\
\text { de kendinizi güvende } \\
\text { hissetmeme nedenleriniz } \\
\text { nelerdir? }\end{array}$} & Denetimsiz Giriş & 69 & 17,3 \\
\cline { 2 - 4 } & $\begin{array}{l}\text { Yerleşke İçerisinde } \\
\text { Diğer İnsanlar }\end{array}$ & Bulunan & 65 & 16,3 \\
\cline { 2 - 4 } & Aydınlatma Yetersizliği & 281 & 70,3 \\
\cline { 2 - 5 } & Gelişigüzel Bitkilendirme & 64 & 16,0 \\
\cline { 2 - 5 } & Başıboş Dolaşan Hayvanlar & 246 & 61,5 \\
\hline
\end{tabular}

Katılımcıların yerleşke aydınlatma tasarımı ile ilgili güvenliğe yönelik düşünceleri alanlar hakkındaki görüşleri Tablo 11'de gösterilmiştir. Kat1lımcıların \% 79,5'i yerleşke içerisinde araç yollarının aydınlatma açısından yeterli olduğunu, \% 55,0'ı ise yaya yollarının aydınlatma açısından uygun olduğunu düşündüklerini belirlenmişlerdir

Kullanıcıların aydınlatma tasarımı hakkındaki düşünceleri Tablo 12 'de verilmiştir. Katılımcıların \% 56,8'i yerleşke de bulunan aydınlatma 
elemanlarının dağılımını normal bulurken, \% 37,5'i gelişigüzel bulmaktadir.

Tablo 11. Katılımcılarn yerleşkenin güvenliği ile ilgili düşünceleri

\begin{tabular}{|c|c|c|c|c|c|c|}
\hline & \multicolumn{3}{|c|}{$\begin{array}{l}\text { Sizce yerleşke üzerinde kendi- } \\
\text { nizi en az güvende hissettiğiniz } \\
\text { alanlar nerelerdir? }\end{array}$} & \multicolumn{3}{|c|}{$\begin{array}{l}\text { Sizce yerleşkede aydınlatma } \\
\text { açısından yeterli olduğunu dü- } \\
\text { şündüğ̈üüz alanlar nerelerdir? }\end{array}$} \\
\hline & Say1 & Yüzde & Sh. & Say1 & Yüzde & Sh. \\
\hline Orman Alanları & 299 & 74,8 & \multirow{7}{*}{,331 } & - & - & \multirow{7}{*}{,406 } \\
\hline Yaya Yolları & 50 & 12,5 & & 220 & 55,0 & \\
\hline Araç Yolları & 32 & 8,0 & & 318 & 79,5 & \\
\hline Yeşil Alanlar & 106 & 26,5 & & 46 & 11,5 & \\
\hline Su Öğeleri & 3 & 7,8 & & 32 & 8,0 & \\
\hline Yap1 Çevreleri & 95 & 23,8 & & 108 & 27,0 & \\
\hline Hepsi & - & - & & 5 & 1,3 & \\
\hline
\end{tabular}

Tablo 12. Kullanıcıların aydınlatma tasarımı hakkındaki düşünceleri

\begin{tabular}{|c|c|c|c|c|c|c|c|}
\hline & \multicolumn{3}{|c|}{$\begin{array}{l}\text { Yerleşke içerisinde } \\
\text { aydınlatma sizce nasıl } \\
\text { olmalıdır? }\end{array}$} & \multicolumn{4}{|c|}{$\begin{array}{l}\text { Sizce yerleşkenin aydınlatma } \\
\text { tasarımı nasıl? }\end{array}$} \\
\hline & Say1 & Yüzde & Sh. & & Sayı & Yüzde & Sh. \\
\hline Çok parlak & 190 & 47,5 & \multirow{3}{*}{,496 } & Rastgele & 175 & - & \multirow{3}{*}{,499 } \\
\hline Az Parlak & 175 & 43,8 & & Yeterli & 185 & 55,0 & \\
\hline \multirow[t]{3}{*}{ Ay Işı̆̆1 } & 61 & 15,3 & & Profesyonel & 36 & 79,5 & \\
\hline & \multicolumn{3}{|c|}{$\begin{array}{l}\text { Sizce aydınlatma elemanları } \\
\text { nın dağılımı nasıl? }\end{array}$} & & & & \\
\hline & Say1 & Yüzde & Sh. & & & & \\
\hline Gelişigüzel & 150 & 37,5 & \multirow{3}{*}{,587 } & & & & \\
\hline Normal & 227 & 56,8 & & & & & \\
\hline Estetik & 30 & 7,5 & & & & & \\
\hline
\end{tabular}

Kullanıcıların aydınlatma ile ilgili görüşleri Tablo 13'de verilmiştir.

Tablo 13. Kullanıcıların aydınlatma ile ilgili görüşleri

\begin{tabular}{|c|c|c|c|c|}
\hline Sorular & Cevaplar & Say1 & Yüzde & Sh \\
\hline \multirow{5}{*}{$\begin{array}{l}\text { İyi bir aydınlatma yapılması } \\
\text { yerleşkenin akşam/gece saatle- } \\
\text { rinde kullanımını artıracaktır. }\end{array}$} & Kesinlikle Katılmıyorum & 14 & 3,5 & \multirow{5}{*}{,475 } \\
\hline & Katılmıyorum & 20 & 5,0 & \\
\hline & Fikrim Yok & 9 & 2,3 & \\
\hline & Katıliyorum & 266 & 66,5 & \\
\hline & Tamamen Katıliyorum & 91 & 22,7 & \\
\hline \multirow{3}{*}{$\begin{array}{l}\text { Aydınlatması olmayan alanlarda } \\
\text { aydınlatma yapılsaydı akşamla- } \\
\text { r1/geceleri kullanırdım. }\end{array}$} & Kesinlikle Katılmıyorum & 18 & 4,5 & \multirow{3}{*}{,985 } \\
\hline & Katılmiyorum & 26 & 6,5 & \\
\hline & Fikrim Yok & 37 & 9,3 & \\
\hline
\end{tabular}




\begin{tabular}{|c|c|c|c|c|}
\hline & Katıliyorum & 228 & 57,0 & \\
\hline & Tamamen Katıliyorum & 91 & 22,7 & \\
\hline \multirow{5}{*}{$\begin{array}{l}\text { Yerleşkede bulunan bitkilere } \\
\text { özel aydınlatma yapılmalıdır. }\end{array}$} & Kesinlikle Katılmıyorum & 22 & 5,5 & \multirow{5}{*}{1,054} \\
\hline & Katılmiyorum & 67 & 16,8 & \\
\hline & Fikrim Yok & 68 & 17,0 & \\
\hline & Katıliyorum & 203 & 50,7 & \\
\hline & Tamamen Katıliyorum & 40 & 10,0 & \\
\hline \multirow{5}{*}{$\begin{array}{l}\text { Yerleşke içerisindeki su öğeleri- } \\
\text { ne özel aydınlatma yapılmalıdır. }\end{array}$} & Kesinlikle Katılmıyorum & 18 & 4,5 & \multirow{5}{*}{1,057} \\
\hline & Katılmiyorum & 56 & 14,0 & \\
\hline & Fikrim Yok & 21 & 5,3 & \\
\hline & Katıliyorum & 233 & 58,2 & \\
\hline & Tamamen Katıliyorum & 72 & 18,0 & \\
\hline \multirow{5}{*}{$\begin{array}{l}\text { Yerleşke içerisinde bulunan } \\
\text { heykellere özel aydınlatma } \\
\text { yapılmalıdır. }\end{array}$} & Kesinlikle Katılmıyorum & 14 & 3,4 & \multirow{5}{*}{1,162} \\
\hline & Katılmiyorum & 76 & 19,0 & \\
\hline & Fikrim Yok & 23 & 5,8 & \\
\hline & Katıllyorum & 220 & 55,0 & \\
\hline & Tamamen Katıliyorum & 67 & 16,8 & \\
\hline \multirow{5}{*}{$\begin{array}{l}\text { Yerleşke içerisinde farklı renk- } \\
\text { lerde aydınlatmalar kullanılma- } \\
\text { lıdır. }\end{array}$} & Kesinlikle Katılmıyorum & 9 & 2,3 & \multirow{5}{*}{893} \\
\hline & Katılmiyorum & 47 & 11,7 & \\
\hline & Fikrim Yok & 29 & 7,2 & \\
\hline & Katıliyorum & 257 & 64,3 & \\
\hline & Tamamen Katıliyorum & 58 & 14,5 & \\
\hline \multirow{5}{*}{$\begin{array}{l}\text { Yerleşke içerisinde karanlıkta hiç } \\
\text { bir yer kalmamalıdır. }\end{array}$} & Kesinlikle Katılmiyorum & 19 & 4,8 & \multirow{5}{*}{1,465} \\
\hline & Katılmiyorum & 93 & 23,3 & \\
\hline & Fikrim Yok & 26 & 6,3 & \\
\hline & Katıliyorum & 169 & 42,3 & \\
\hline & Tamamen Katılıyorum & 93 & 23,3 & \\
\hline \multirow{5}{*}{$\begin{array}{l}\text { Yerleşkede aydınlatma yapılma- } \\
\text { s1 elektrik tüketimini artıracağ1 } \\
\text { için gereksizdir. }\end{array}$} & Kesinlikle Katılmıyorum & 162 & 40,5 & \multirow{5}{*}{,818 } \\
\hline & Katılmiyorum & 186 & 46,5 & \\
\hline & Fikrim Yok & 17 & 4,3 & \\
\hline & Katıliyorum & 31 & 7,7 & \\
\hline & Tamamen Katılıyorum & 4 & 1,0 & \\
\hline
\end{tabular}

\section{Tartışma}

Yerleşkede, kullanıcı görüşleriyle de desteklenen bir güvensizlik duygusu sorunu bulunmaktadır. Bu duygunun oluşumunu, yerleşkedeki aydınlatmanın yetersiz olmasına bağlayan kullanıcıların oranı $\% 52$ 'dir. Ayrıca kullanıcıların \% 24'ü yerleşkenin genel aydınlatmasını yetersiz, \% 55 'i ise kısmen yeterli olarak değerlendirmişlerdir. Yetersiz aydınlatma, görüş koşullarını zorlaştırarak çevresel algıyı kısıtlamakta ve kullanıcıların kendini güvensiz hissetmesine neden olmaktadır. 
Özellikle öğrencilerin kaldığı yurtların olduğu bölgede yaşanan yetersiz aydınlatma sorunu bu yurtlara erişimi zorlaştırmaktadır. Aydınlık düzeyinin en düşük olduğu, ş̧ığın yetersiz kaldığı bölgeleri ş̧ık ölçümüyle oluşturulmuş olan aydınlık haritası üzerinde de tespit etmek mümkündür.

Yapılan anket çalışması sonucunda; cinsiyet, yaş ve eğitim durumuna göre tercihlerin değişip değişmediğinin belirlenmesi amacıyla SPSS 20.0 yazılımında ki-kare testi uygulanarak çapraz sorgulama yapılmıştır. Cinsiyete göre yerleşkenin güvenli bulunup bulunmadığı ile ilgili analiz Tablo 14'de verilmiştir.

Tablo 14. Cinsiyet ile yerleşke güvenliğinin niteliği ki-kare çizelgesi

\begin{tabular}{|c|c|c|c|c|c|}
\hline \multirow{9}{*}{ Cinsiyetiniz } & \multicolumn{5}{|c|}{ Yerleşkeyi gece/akşam güvenli buluyor musunuz? } \\
\hline & & & Evet & Hayır & TOPLAM \\
\hline & \multirow{2}{*}{ Erkek } & $\mathrm{N}$ & 124 & 105 & 228 \\
\hline & & $\%$ & 54,1 & 45,9 & 100,0 \\
\hline & \multirow{2}{*}{ Kadın } & $\mathrm{N}$ & 68 & 103 & 171 \\
\hline & & $\%$ & 39,8 & 60,2 & 100,0 \\
\hline & \multirow{2}{*}{ TOPLAM } & $\mathrm{N}$ & 192 & 208 & 400 \\
\hline & & $\%$ & 48,0 & 52,0 & 100,0 \\
\hline & \multicolumn{5}{|c|}{$\mathrm{X}^{2}=8,131 \mathrm{sd}=1 \mathrm{P}=, 142$ Cramer's $\mathrm{V}=, 142 \mathrm{p}<0,05$} \\
\hline
\end{tabular}

Yapılan analiz sonucunda; çalışmaya katılan kadınların çoğunun yerleşkeyi güvenli bulmadığı belirlenirken, erkeklerin ise yerleşkeyi güvenli buldukları belirlenmiştir. Cinsiyete göre yerleşkenin aydınlık düzeyi ile ilgili görüşlere yönelik yapılan testin sonuçları Tablo 15'de verilmiştir.

Tablo 15. Cinsiyet ile yerleşke aydınlık düzeyi niteliği ki-kare çizelgesi

\begin{tabular}{|c|c|c|c|c|c|c|}
\hline \multirow{9}{*}{ Cinsiyetiniz } & \multicolumn{6}{|c|}{ Yerleşkedeki genel aydınlık düzeyi sizce yeterli mi? } \\
\hline & & & Evet & Hayır & Kismen & TOPLAM \\
\hline & \multirow{2}{*}{ Erkek } & $\mathrm{N}$ & 69 & 39 & 121 & 229 \\
\hline & & $\%$ & 30,2 & 17,0 & 52,8 & 100,0 \\
\hline & \multirow{2}{*}{ Kadın } & $\mathrm{N}$ & 15 & 57 & 99 & 171 \\
\hline & & $\%$ & 8,8 & 33,3 & 57,9 & 100,0 \\
\hline & \multirow{2}{*}{ TOPLAM } & $\mathrm{N}$ & 84 & 96 & 220 & 400 \\
\hline & & $\%$ & 21,0 & 24,0 & 55,0 & 100,0 \\
\hline & \multicolumn{6}{|c|}{$\mathrm{X}^{2}=32,564 \mathrm{sd}=2 \mathrm{P}=, 285$ Cramer's $\mathrm{V}=, 285 \mathrm{p}<0,05$} \\
\hline
\end{tabular}


Erkek ve kadınların büyük bir kısmının yerleşkenin genel aydınlık düzeyinin kısmen yeterli olduğunu düşündükleri tespit edilmiştir. Ancak erkeklerin kısmen tercihlerinin arkasından çoğunlukla yerleşkenin aydınlık düzeyini yeterli gördüğü, kadınların ise yeterli görmediği sonucuna ulaşılmıştır. Cinsiyete göre çevreyi algılama durumu ile ilgili yapılan ki-kare testi sonuçları Tablo 16'da verilmiştir.

Tablo 16. Cinsiyet ile yerleşke çevreyi algılama niteliği ki-kare çizelgesi

\begin{tabular}{|c|c|c|c|c|c|c|}
\hline \multirow{9}{*}{ Cinsiyetiniz } & \multicolumn{6}{|c|}{ Yerleşkede geceleri çevrenizi algılamakta sorun yaşıyor musunuz? } \\
\hline & & & Evet & Hayır & Kismen & TOPLAM \\
\hline & \multirow{2}{*}{ Erkek } & $\mathrm{N}$ & 62 & 125 & 42 & 229 \\
\hline & & $\%$ & 27,1 & 54,6 & 18,3 & 100,0 \\
\hline & \multirow{2}{*}{ Kadın } & $\mathrm{N}$ & 57 & 39 & 75 & 171 \\
\hline & & $\%$ & 33,3 & 22,8 & 43,9 & 100,0 \\
\hline & \multirow{2}{*}{ TOPLAM } & $\mathrm{N}$ & 119 & 164 & 117 & 400 \\
\hline & & $\%$ & 29,8 & 41,0 & 29,2 & 100,0 \\
\hline & $X^{2}=47,198$ & $44 \mathrm{C}$ & 's V = & $4 \mathrm{p}<0$ & & \\
\hline
\end{tabular}

Erkeklerinin büyük çoğunluğunun yerleşke içerisinde çevreyi algılamada sorun yaşamadığı, kadınların ise kısmen sorun yaşadığı tespit edilmiştir. Yaş gruplarına göre, yerleşkenin güvenli bulunup bulunmaması ile ilgili ki-kare testi sonuçları Tablo 17' de verilmiştir.

Analiz sonuçlarına göre 15-20, 31-40, yaş grupları arasının yerleşkeyi güvenli bulduğu, 21 - 30 arası yaş grubu ve 40 yaş üstü grupların yerleşkeyi akşam güvenli bulmadıkları tespit edilmiştir. Yaş grupları arasında 40 yaş üstü kişilerin yerleşkeyi akşam/gece kullanımında çevreyi algılamada sorun yaşadığı, diğer yaş gruplarının ise sorun yaşamadığı sonucuna ulaşılmıştır. 15 - 25 yaş grubu arasındaki kişilerin yerleşkenin aydınlatma tasarımını kısmen yeterli bulduğu, 26 yaş üstü kişilerin ise yerleşkenin aydınlatma tasarımını yeterli bulmadığı sonucuna ulaşılmıştır $(p<0,05)$. Eğitim durumu ile yerleşkenin güvenliğinin niteliğinin belirlenmesi yönelik ki-kare testi yapılmıştır. Yapılan analizler sonucunda; lisans, yüksek lisans ve doktora düzeyindeki kişilerin yerleşkeyi akşam/gece güvenli bulmadığı, ilköğretim ve lise düzeyindeki kişilerin yerleşkeyi akşam/gece güvenli buldukları sonucuna ulaşılmıştır $(\mathrm{p}<$ $0,05)$. Lisans ve yüksek lisans mezunlarının yerleşkenin genel aydınlık düzeyini yeterli bulmadıkları, ilköğretim ve doktora mezunlarının ise yeterli buldukları sonucuna ulaşılmıştır $(p<0,05)$. 
Aydınlatma ile Güvenlik Algısı İlişkisinin Niğde Ömer Halisdemir Üniversitesi Yerleşkesi

Örneğinde İncelenmesi

Tablo 17. Yaş ile yerleşke güvenliğinin niteliği ki-kare çizelgesi

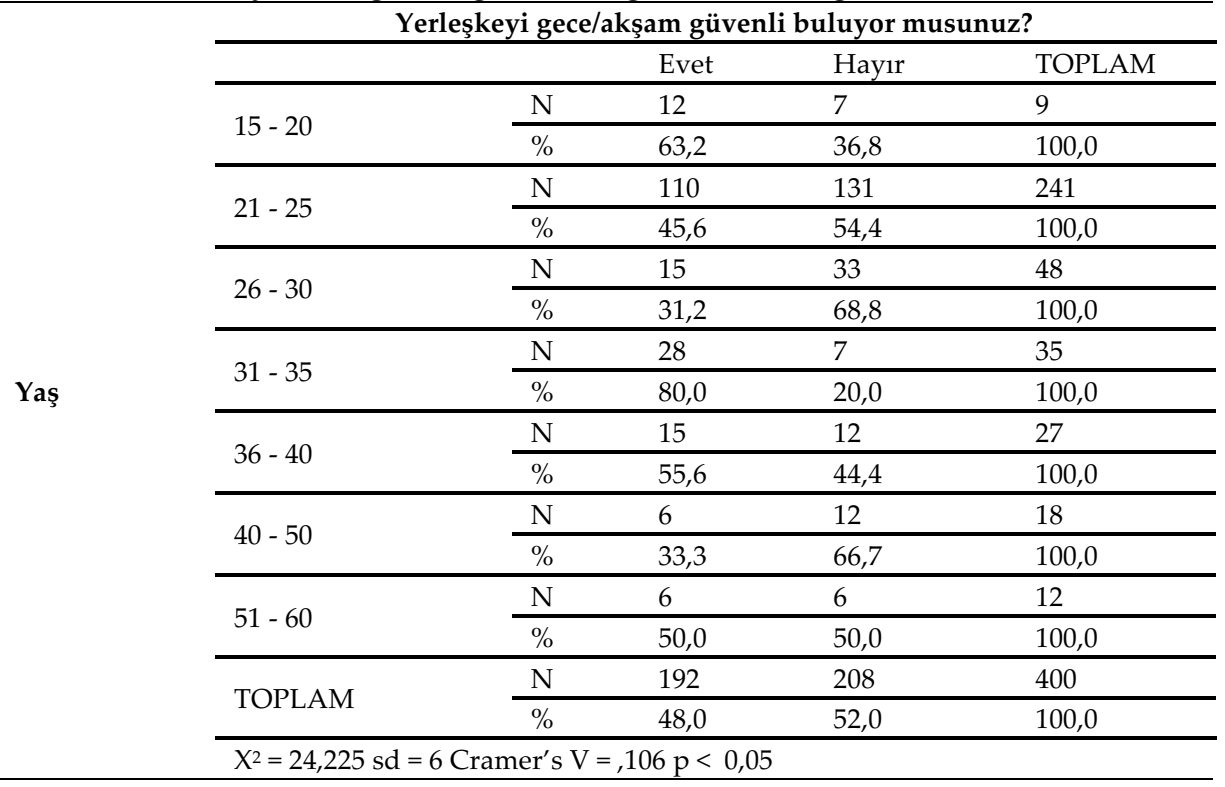

Katılımcların genel aydınlatma ile ilgili düşüncelerine verdikleri soruların ortalamaları Tablo 18'de verilmiştir.

Tablo 18. Katılımcılarn genel aydınlatma ile ilgili düşüncelerine verdikleri sorularin ortalamalarn

\begin{tabular}{lll}
\hline Tercihler & Ortalama & Standart Hata \\
\hline $\begin{array}{l}\text { İyi bir aydınlatma yapılması yerleşkenin } \\
\text { akşam/gece saatlerinde kullanımını artıracaktır. }\end{array}$ & 4,00 &, 875 \\
\hline $\begin{array}{l}\text { Aydınlatması olmayan alanlarda aydınlatma } \\
\text { yapılsaydı akşamları/geceleri kullanırdım. }\end{array}$ & 3,87 &, 985 \\
\hline $\begin{array}{l}\text { Yerleşkede bulunan bitkilere özel aydınlatma } \\
\text { yapılmalıdır. }\end{array}$ & 3,43 & 1,054 \\
\hline $\begin{array}{l}\text { Yerleşke içerisindeki su öğelerine özel aydınlatma } \\
\text { yapılmalıdır. }\end{array}$ & 3,71 & 1,057 \\
\hline $\begin{array}{l}\text { Yerleşke içerisinde bulunan heykellere özel } \\
\text { aydınlatma yapılmalıdır. }\end{array}$ & 3,62 & 1,078 \\
\hline $\begin{array}{l}\text { Yerleşke içerisinde farklı renklerde aydınlatmalar } \\
\text { kullanılmalıdır. }\end{array}$ & 3,77 &, 916 \\
\hline Yerleşke içerisinde karanlıkta hiç bir yer kalmamalıdır. & 3,56 & 1,210 \\
\hline $\begin{array}{l}\text { Yerleşkede aydınlatma yapılması elektrik tüketimini artıracağı } \\
\text { için gereksizdir. }\end{array}$ & 1,82 &, 904 \\
\hline
\end{tabular}


Yapılan anket çalışması sonucunda yerleşke içerisindeki kullanıcıların yerleşkenin aydınlatma durumunu kısmen yeterli buldukları tespit edilmiştir. Kullanıcıların büyük bir çoğunluğunun iyi bir aydınlatma olması durumunda akşam/gece saatlerinde yerleşke içerisinde daha çok vakit geçireceği belirlenmiştir. Bunun yanında yerleşke içerisinde aydınlatma tasarımının belirli alanlarda (heykel, bitki, su öğeleri vb.) o alanlara özel olmasının kullanıcılar tarafından daha ilgi çekici duruma geleceği belirlenmiştir. Fakat bu tasarımların yerleşke içerisinde her yere değil, yerleşkenin merkezi alanlarına yapılmasının daha uygun olacağı tespit edilmiştir. Kullanıcılar, yerleşke aydınlatma tasarımında güvenliğin en önemli etken olduğunu düşünürken bunun yanında ekonomik unsurlarında düşünülmesi gerektiğini savunmaktadırlar.

Kullanıcılar açısından yerleşke içerisinde aydınlatma sorununun ardından en büyük sorunun, yerleşke içerisinde bulunan hayvanlar olduğu tespit edilmiştir. Özellikle aydınlatma açısından eksik ya da tamamen karanlık olan alanlarda belirli hayvanların bulunduğu ve bunun da yerleşkede bulunanlarının kullanımını etkilediği tespit edilmiştir. Bu bakımdan bu alanların aydınlatılması ve kullanıcıları açısından görünürlüğünün artırılmasının kullanıcılar açısından yararlı olacağı tespit edilmiştir.

Yapılan anket çalışması sonucundan kullanıcıların \% 41'inin çevreyi algılamada sorun yaşamadığını, ancak kullanıcıların \% 61,2'sinin yerleşke aydınlatma tasarımının daha iyi olabileceğini istedikleri tespit edilmiştir. Bunun sebebinin ise yerleşke içerisindeki kullanıcıların rekreasyonel faaliyet açısından çok fazla aktivite olmamasından dolayı akşam saatlerinde pek fazla zaman geçirmedikleri tespit edilmiştir. Kullanıcıların \% 48,5'nin yerleşkeyi akşam saatlerinde sadece ders sonrası kısa süreli etkinlikler için kullandıkları tespit edilmiştir. Bu yüzden öğrenciler özellikle yerleşke içerisinde yer alan Akkaya barajı ve çevresinin daha etkili bir şekilde planlanması gerektiğini ve bu alanlara yönelik iyi bir aydınlatma planlamasının yapılması ile yerleşkenin akşam saatlerindeki kullanımının artacağı tespit edilmiştir.

Kullanıcıların \% 74,8'i yerleşke içerisindeki orman alanlarında kendilerini en az güvende hissettiklerini belirtirken, \% 79,5'inin ise en çok araç yollarında kendilerini güvende hissettiklerini belirttikleri tespit edilmiştir. Gerek bilgisayar ortamında gerekse alan analizleri sonucunda elde 
edilen bilgiler de bu sonucu destekler şekildedir. Bilgisayar ortamından ortalama 1,2 lüks ile en az aydınlatma düzeyine sahip alanlar orman alanları olurken, ortalama 21 lüks ile en yüksek aydınlatmaya sahip alanlar araç yolları olmuştur.

\section{Sonuç}

Peyzaj mimarlığı, peyzaj ve yapısını oluşturan doğal etmenlerin özelliklerini araştırarak, ekolojik planlama, alan kullanım planlaması, su, toprak ve görsel değerlerin korunması, doğa onarımı, kentsel ve kırsal çevrede rekreasyonel amaçlı kullanım alanları oluşturması ve tasarım uygulama aşamasında canlı ve cansız malzeme ile çevreye duyarlı işlevsel ve estetik yaşama mekanları oluşturmasında görev alır. Bunun sonucunda kullanım alanları oluşturmada rengin ve ışığın doğru kullanımını sağlamak, insana verilen önemi arttırmakta, çevre ve insan arasındaki ilişkinin bütünleşmesini sağlamaktadır (Alper, 2002, s.18).

Niğde Ömer Halisdemir Üniversitesi Yerleşkesi, Niğde İl'inin merkezi niteliğindedir. Çok sayıda öğrenci ve çalışanın kullandığı, barındığı yarı kamusal kentsel bir mekândır. Burada bulunan aydınlatma sistemleri; öğrencilerin eğitimlerini ve sosyal yaşantılarını, kısaca yaşam kalitelerini etkilemektedir. Dolayısıyla, geceleri yaklaşık bin kişinin aktif olarak kullandığı bu yerleşke, görsel konfor koşullarına uyan sağlıklı bir gece aydınlatmasına ihtiyaç duymaktadır.

Niğde Ömer Halisdemir Üniversitesi yerleşkesi içerisinde bulunan Akkaya Barajının aydınlatılması daha çok ekolojik unsurlar düşünülerek yapılmalıdır. Bu tür suların, havuzlar gibi içten aydınlatılması çok pahalı ve kimi zaman olanaksızdır. Bu nedenle, su kenarında yer alan ağaç, çim alanı vb. nesnelerin aydınlatılarak, bunların su yüzeyindeki görüntüleri aracılığı ile algılanmasını olanaklı kılan düzenler kurulmalıdır. Çok fazla aydınlatma şiddeti olan lamba ve armatürler tercih edilmemelidir. Geleneksel sodyum ya da cıva buharlı lambaların yerine LED veya Projektör tipi aydınlatma elemanları tercih edilmelidir. Böylece Akkaya Barajı çevresinde bulunan ağaç ve çeşitli nesnelerin aydınlatma sayesinde yans1maları ile görsel çeşitlilik sağlanabilir

Yerleşke içerisinde aydınlatma tasarımı yapılmadan önce çok iyi bir alan analizinin yapılması gerekmektedir. Güncel bitkilerin korunması 
gerekmektedir. Bu bitkilerin konumunun 1şı̆̆ın düştüğü noktalara gelmesi sebebiyle aydınlatmada enerji kayıpları ortaya çıkabilmektedir. Bu yüzden aydınlatma elemanları konumlandırılmadan önce güncel bitkilerin yerleri saptanmalı, aydınlatma direkleri bu bitkilerin üstüne gelmeyecek biçimde konumlandırılmalıdır. Aydınlatma elemanlarının düşürdüğü ışığı kesen yüksek boylu ağaçların olması durumunda, bu alanlarda zeminin görünmesini sağlayacak yerden aydınlatmalar tercih edilmelidir. Ancak böylece kullanıcıların yerleşkeyi akşam kullanımları kesintisiz bir şekilde sağlanabilmektedir.

Yerleşke kullanıcıları üzerinden yapılan anket çalışması kapsamında aydınlatmanın yerleşke kullanımını etkilediği tespit edilmiştir. Yerleşkede en büyük sorunun aydınlatma olduğunu düşünenlerin oranı \% 70,3'dür. Bunun yanı sıra yerleşke içerisinde aydınlatmanın iyi olması durumundan yerleşkeyi akşamda kullanırım diyenlerin oranı ise \% 89,2'dir. Ayrıca anket çalışmasına katılanların \% 48,5'i yerleşkeyi ders sonrası aktivite amacıyla kullanmak istediği, ancak iyi bir aydınlatma olmamasından dolayı kullanamadıklarını belirtmişlerdir.

$\mathrm{Bu}$ yüzden yerleşke içerisinde yoğun kullanıma sahip yeşil alanlar (kantin, bina giriş-çıkışları, su alanları çevresi vb.) kullanım süreleri de dikkate alınarak sürekli olarak aydınlatılmalı, bu alanlara özel aydınlatma tasarımı yapılarak öğrenciler ve akademisyenlerin yerleşkeyi kullanım süreleri uzatılmalıdır. Bunun için farklı lamba tipleri ve renkleri ile aydınlatma açısından görsel kalite artırılmalı ve cazibe alanları oluşturulmalıdır. Tez çalışması kapsamında yapılan analizler doğrultusunda; iyi bir aydınlatma ile kullanıcıların güvensizlik duygusunun azaldığı ve akşam saatlerinde de kendilerine güvende hissetme oranlarının artacağı tespit edilmiştir.

Ayrıca anket çalışması kapsamında farklı aydınlatma tiplerinin kullanıcılar tarafından tercih edilme oranı ise $\% 76,0^{\prime}$ dır. Bu yüzden bu alanlarda farklı aydınlatma tipleri (vurgu, odak, yerden aydınlatma vb.) kullanılarak alanların çekiciliği arttırılarak kullanıcılar tarafından yerleşkenin kullanım süresi artırılabilir. Bunun için yerleşke içerisinde bulunan peyzaj öğeleri (havuz, heykel, kameriye, donatı elemanları vb.) analiz edilmelidir. Kentsel donatı elemanlarında; her bir kentsel donatı elemanı için ayrı bir aydınlatma tasarımı düşünülmeli, böylece yerleşke daha da çekici duruma getirilebilmektedir. Örneğin heykellerde yerden aydın- 
Aydınlatma ile Güvenlik Algısı İlişkisinin Niğde Ömer Halisdemir Üniversitesi Yerleşkesi Örneğinde İncelenmesi

latma, merdivenlerde gömme aydınlatma tercih edilerek bu alanların güvenliğinin sağlanmasının yanında yerleşke içerisinde odak noktalar oluşturulabilir. 
EXTENDED ABSTRACT

\title{
Investigation of the Relationship Between Lighting and Security Perception in the Case of Niğde Ömer Halisdemir University Campus
}

\author{
Orhun Soydan - Ahmet Benliay \\ Akdeniz University
}

The number of universities is constantly increasing and some of these universities have large campuses in Turkey. Therefore, campus areas have a great importance in urban areas. Students use the campus areas for accommodation, leisure and recreational activities as well as education. These campuses are used during the night as well as during the day. Lighting systems design has an important issue in terms of night use of these areas (safety, aesthetics, etc.). Dark areas have been occurred because the lacks of lighting design in some areas in the campuses, resulting in security problems in the campuses. As a result of the lack of lighting, the animals rambling inside the campuses, physical dangers and fear of being attacked in humans occur. These deficiencies prevent the use of the campuses at night. Fears caused by lighting reduce the quality of life and the comfort of the campuses. With the increase in the number of people living in urban areas, the opportunities offered by the cities to the users are changing and sometimes they are inadequate. This inadequate urban quality of life which is associated with urban areas, leads to a decrease in the trust and satisfaction of the users. Cities provide multi-functional areas as shelter, rest, education etc. to people. Cities enclose residences, trade centers, transportation areas, forests and green areas due to these functions. It is possible to evaluate the campuses as "active green areas" within these concepts. The university campuses which have been turned into big areas within the city, are transformed into large residential areas due to the number of staff and recreation activities. Therefore, campus designs have a great importance in order to increase the active green area in the city. Lighting design is important for 
continuous use of the campuses. Night use of the camps should be increased. Reasons as education, education, dormitory, library, research etc. evening / night use should be provided for use the campuses at night. This can only be achieved with well-planned and designed lighting. With a good lighting design, the use of campuses at night for users can be increased. In this study; survey was conducted on students, academic and administrative personnel and employees (400 people). As a result of the survey; user's opinion about the campus lighting design and how the lighting design affects their use were determined. In addition, security problems related to lighting in the campus were determined according to the opinions of the users of the campus. The relationship between the lighting design and the usage areas in the campus and areas where are the users feel most secure or at feel most least have been determined. There are 9 Faculties, 3 Vocational Schools and 3 colleges on Niğde Ömer Halisdemir University Campus. The campus is divided into 7 classes according to the areas of use. These are highways, roads, patrol roads, parking lots, green areas, cycling routes and sports fields. It is determined that $64,30 \%$ of the settlement is covered with green area and the proportion of faculties, administrative buildings and classrooms within the campus is 5,16\%. Mostly, the respondents were male, aged 21 to 25 years. $66.8 \%$ of the participants are undergraduate students. $92.8 \%$ of the participants use the campus in the evening hours. $94.3 \%$ of the respondents think that the illumination factor affects safety. For general lighting of the campus, $55.0 \%$ of the participants find that is sufficient, but $24.0 \%$ is not sufficient. $61.2 \%$ of the participants said that the general lighting situation of the campus could be better. It was found that $56.3 \%$ of the participants found the number of lighting elements within the campus to be partially sufficient. $41.0 \%$ of the participants have a problem with night perception in the campus. $76.0 \%$ of respondents want a special lighting in open green areas. $56.8 \%$ of the participants used the campus in March-April-May and 53.3\% of them used it in DecemberJanuary-February. $48.5 \%$ of the participants use the campus in the evening for they exited from lecture. While $70.3 \%$ of the participants did not feel safe because of the lack of lighting in the campus, $61.5 \%$ of them stated that they did not feel safe because of the stray animals. $74.8 \%$ of the participants stated that they felt the least secure in the forest areas 
and $26.5 \%$ felt the least secure in the green areas. $79.5 \%$ of the participants stated that vehicle roads were sufficient in terms of lighting and $55.0 \%$ thought that pedestrian roads were sufficient for lighting. As a result of the analysis; while most of the women who participated in the study did not find the campus safe, the males found it safe. For security, lamps and fixtures with too much light intensity should not be preferred. Green areas (canteen, building entrances, exits, water areas etc.) should be continuously illuminated by taking into consideration the duration of use and special lighting design for these areas should be extended to students and academicians. The whole campus should not be illuminated. The needs of the users should be determined and a suitable lighting plan should be made for these criteria.

\section{Kaynakça / References}

Alper, H. (2002). Peyzaj mimarlı̆̆ında ışık ve renk kullanımının Erzurum Kenti örneğinde incelenmesi. Yüksek Lisans Tezi, Atatürk Üniversitesi, Fen Bilimleri Enstitüsü, Peyzaj Mimarlı̆̆ 1 Anabilim Dalı, Erzurum.

Caşın, M. H., Özgöker, U. ve Çolak, H. (2007). Küreselleşmenin Avrupa Birliği ortak güvenlik ve savunma politikasına etkisi: Avrupa Birliği. İçinde (s.189), Ankara:Nokta Kitap.

Çelik, F., Gemici, R. Ö. ve Mirza, E. (2018). Öğrencilerin Alaeddin Keykubad kampüsü fiziksel çevresine ilişkin güvenlik algıları. OPUSUluslararası Toplum Araştırmaları Dergisi, 9(16), 216-247. DOI: 10.26466/opus. 453200.

Dedeoğlu, İ., (2006). Kentsel yeşil alanların gece kullanımında dış aydınlatmanın önemi ve yöntemi: Gülhane Parkı örneği. Yüksek Lisans Tezi. Bahçeşehir Üniversitesi, Fen Bilimleri Enstitüsü, Çevre Tasarımı Anabilim Dall, İstanbul.

Emür, S. H. (2007). Kentsel yaşam kalitesi bileşenleri arasında açık ve yeşil alanların önemi:Kayseri/Kocasinan İlçesi park alanları analizi. Sosyal Bilimler Enstitüsü Dergisi, 22, 367-396.

Gök, Z., (2018). Kentsel açık-yeşil alanlarda kullanıcıların güvenlik algısı: Isparta kenti örneği. Doktora Tezi, Süleyman Demirel Üniversitesi, Fen Bilimleri Enstitüsü, Peyzaj Mimarlığ Anabilim Dalı, Isparta.

Lang, J. (1994). Urban design: the American experience. Yer:John Wiley \& Sons. 
Maslow, A.H. (1970). A theory of human motivation. Psychological Review, 50, 370-39.

Özcan, A., (2011), Uluslararası güvenlik sorunları ve ABD'nin güvenlik stratejileri. Selçuk Üniversitesi İ̈BF Sosyal ve Ekonomik Araştırmalar Dergisi, 22, 451-470.

Öztürk, O. (2014). Okul, kampüs güvenliği ve olası riskler. Güvenlik Yönetimi Dergisi, 16, 54-57.

Öztürk, L. ve Ünver, R., (1992). Değişik yapı yüzeylerinin aydınlatılmasında temel özellikler. Şehir Aydınlatması Kolokyumu, içinde (s.19-30), Kocaeli:TMMOB Elektrik Mühendisleri Odası.

Rund, A.J. (2002). The changing context of campus safety. New Directions for Student Services, 99, 3-10.

Sankır, H., Demir ve Gürdal, A., (2014). Bülent Ecevit Üniversitesi'nin Zonguldak'a etkileri ve kentin üniversite alg1sı. Journal of Higher Education and Science/Yüksekögretim ve Bilim Dergisi, 4(2), 40.

Seçkin, Ö. B., (1998). Peyzaj uygulama tekniği, Ders Notu s: 67, İstanbul Üniversitesi, Orman Fakültesi, Peyzaj Mimarlığı Bölümü, İstanbul.

Waters, J., Neale, R.H. ve Mears, K. (2005). Perceptions of personal safety in relation to the physical environment of university campuses. In $C I B$ Joint Symposium on Advancing Facilities Management and Construction through Innovation, (230-242), June 13-16 2005, Helsinki.

Yazıcıoğlu, Y., ve Erdoğan, S. (2014). SPSS uygulamalı bilimsel araştırma yöntemleri. Yer:Detay Yayıncilik.

\section{Kaynakça Bilgisi / Citation Information}

Soydan, O. ve Benliay, A. (2019). Aydınlatma ile güvenlik algısı ilişkisinin Niğde Ömer Halisdemir Üniversitesi yerleşkesi örneğinde incelenmesi. OPUS-Uluslararası Toplum Araştırmaları Dergisi, 14(20), 878-904. DOI: 10.26466/opus.560247 